JEP | Volume 3 | Nomor 2| November 2019

e-ISSN 2579-860X

Jurnal Eksakta Pendidikan (JEP)

p-ISSN 2614-1221

http://jep.ppj.unp.ac.id/index.php/jep

Doi: https://doi.org/10.24036/jep/vol3-iss1/328

\title{
Program Belajar berbasis STEM untuk Pembelajaran IPA: Tinjauan Pustaka, dengan Referensi di Indonesia
}

\author{
Oktian Fajar Nugroho*, Anna Permanasari, Harry Firman \\ Sekolah Pascasarjana Pendidikan IPA, Universitas Pendidikan Indonesia, Indonesia \\ E-mail*: oktianfajarnugroho@upi.edu
}

\begin{abstract}
The scenario of Industry 4.0 and $21^{\text {st }}$ century skills show rapidly increase and informed. In this century, the main goal of our educational system should be able to answer students needed for living in the world. In recent years, STEM Education has received growing attention to be considered to understand STEM Education. In the South East Asia, Indonesia is one of the biggest country has a large number of human resources that should be developed. This study was aimed to examine the movement of STEM education in Indonesia within the scope of $21^{\text {st }}$ century skills categories by using the content analysis method, examine best practice of STEM education for teachers by investigating engineering design skills training and reviewed the literature from 1990 to 2016 that has emphasized on development of STEM education around the world. The findings showed that STEM Education has been developed around Indonesia and has a positive impact to enhance students' concept comprehension, literacy, and creativity. Many researches provide evidence the best practice for science teacher to implement STEM Education. STEM has a close to daily life and increase student awareness with the environment.
\end{abstract}

Keywords: STEM education, $21^{\text {st }}$ century skills.

This is an open access article distributed under the Creative Commons 4.0 Attribution License, which permits unrestricted use, distribution, and reproduction in any medium, provided the original work is properly cited. $₫ 2019$ by author and Universitas Negeri Padang.

\section{PENDAHULUAN}

Pada abad ke-21 terdapat keterampilan yang perlu dikuasi, hal tersebut ditunjukkan dengan peningkatan informasi yang cepat. Di abad ini, tujuan utama sistem pendidikan kita harus dapat menjawab kebutuhan siswa. Abad ke-21 ditandai oleh perkembangan pesat ilmu pengetahuan, teknologi, teknik, dan matematika (STEM). Gerakan ini mempengaruhi kualitas hidup manusia dan menyebabkan perubahan dalam semua aspek kehidupan manusia. Meskipun berubah, perubahan tersebut memiliki dampak positif dan dampak negatif. Sementara itu, dampak positifnya adalah teknologi telah meningkat pesat. Dalam beberapa tahun terakhir, Pendidikan STEM telah menarik perhatian yang semakin besar untuk dipertimbangkan. Menurut beberapa artikel jurnal, pendidikan STEM telah didefinisikan dengan beragam mulai dari pendekatan disiplin hingga trans disiplin (Burke et al., 2014; Honey et al., 2014; Moore dan Smith, 2014).

Pendidikan STEM adalah pendekatan interdisipliner pembelajar di mana konsep dan teori dalam rumpun diintegrasikan dengan pelajaran dunia nyata pada saat siswa menerapkan sains, teknologi, teknik, dan matematika dalam konteks yang membuat koneksi antara sekolah, komunitas, pekerjaan, dan perusahaan global yang memungkinkan dalam ekonomi baru (Teupros, Kohler, \& Hallinen, 2009). Menurut Bybee (2013), pendekatan STEM memiliki kaitan erat dengan aktivitas dunia nyata yang melibatkan empat disiplin ilmu seperti Sains, Teknologi, Teknik, dan Matematika yang harus diajarkan secara terintegrasi. Tujuan Pendidikan STEM berdasarkan Bybee (2013) adalah untuk semua siswa saat belajar dan menerapkan konten dasar dari disiplin ilmu tersebut dan praktik disiplin STEM pada situasi kehidupan nyata. Kurikulum tersebut harus memberikan keterampilan memperoleh informasi alih-alih memberi mereka pemahaman pengetahuan tentang suatu konsep. Mengenai perspektif tersebut, bagaimana kurikulum memberikan ruang pada siswa dalam kehidupan nyata dan memungkinkan siswa untuk menggunakan pengetahuan dan keterampilan yang mereka butuhkan untuk menjadi warga negara yang berpengetahuan.

Di Asia Tenggara, Indonesia adalah salah satu negara terbesar yang memiliki banyak sumber daya manusia yang harus 
dikembangkan. Data dari BPS - Biro Pusat Statistik Indonesia (2010) menunjukkan bahwa tenaga kerja Indonesia masih didominasi oleh 88 juta tenaga kerja tidak terampil. 22,1 juta pekerja terampil dan hanya 6,5 juta dikuasai di sektor mereka. Berdasarkan informasi yang ditunjukkan di atas, Indonesia harus lebih siap dan lebih banyak upaya untuk meningkatkan dan meningkatkan pemahaman siswa tentang STEM. Pada dasarnya, dalam implementasi sebelum pemahaman siswa tentang STEM itu sendiri kita harus mempertimbangkan guru yang akan mengimplementasikan STEM di kelas mereka. Guru akan menjadi garda terdepan untuk Indonesia sebagai fasilitator Pendidikan STEM.

STEM pada dasarnya penting bagi generasi kita untuk hidup sebagai masyarakat modern. STEM memberdayakan generasi kita dalam banyak hal penting. Mengenai STEM, pertanyaan mendasar tentang alam dan bagaimana memahami dunia dapat diberikan oleh sains dan matematika.

Istilah-istilah berikut dari referensi menjelaskan ruang lingkup pendidikan STEM yang terbatas pada pendidikan Dasar dan Pascasekolah:

1. Ruang lingkup guru untuk pendidikan STEM (disebut pendidikan guru awal)

2. Metode terbaik untuk mendukung kondisi guru STEM saat ini berfokus pada kelanjutan pengembangan profesional.

3. Pengenalan pengajaran dan pembelajaran yang akan meningkatkan pendidikan STEM

4. Peningkatan pembelajaran dengan menggunakan teknologi digital.

5. Metode mempromosikan dan meningkatkan motivasi dan keterlibatan siswa untuk mengambil bagian dalam mata pelajaran rumpun STEM.

Artikel ini bertujuan untuk memastikan pendidikan STEM di Indonesia memiliki Kualitas Internasional tertinggi. Sementara itu, tingkat kinerja. Jadi, kualitas calon guru dan diharapkan akan meningkat secara signifikan dan berkelanjutan. Utilitas pendidikan STEM terbukti, berdasarkan pekerjaan yang terkait dengan STEM diproyeksikan akan tumbuh menjadi lebih dari 9 juta antara 2012 dan 2020 (Vilorio, 2014).

\section{METODE PENELITIAN}

Dalam penelitian ini, urgensi pendidikan STEM di Indonesia diperiksa dalam lingkup kategori keterampilan abad ke-21 dengan menggunakan metode analisis konten. Analisis konten adalah teknik penelitian yang memungkinkan para peneliti untuk menyelidiki perilaku manusia secara tidak langsung dengan menganalisis produk mereka seperti buku teks, artikel, surat kabar, iklan, lagu, pernyataan politik, novel, gambar dan hampir semua jenis komunikasi. Selain itu, melalui pemeriksaan publikasi profesional dan umum, analisis konten memfasilitasi investigasi arah perubahan dalam pendidikan (Fraenkel, Wallen \& Hyun, 2012). Demikian pula, dalam penelitian ini, praktik terbaik pendidikan STEM untuk guru diselidiki berkaitan dengan pelatihan keterampilan desain teknik. Penelitian ini mengulas literatur dari tahun 1990 hingga 2016 yang menekankan pada pengembangan pendidikan STEM di Indonesia.

Prosedur penelitian dilakukan dengan merujuk kepada alur penelitian survey. Instrumen yang digunakan adalah jurnal penelitian pendekatan STEM dan kuesioner guna menunjang hasil analisis jurnal. Kuesioner diberikan kepada guru SMP yang disebar di beberapa kota di Indonesia diantaranya pulau Sumatra dan pulau Jawa. Hasil responden sebanyak 113 orang guru SMP.

\section{HASIL DAN PEMBAHASAN}

a) Urgensi Pendidikan STEM ke Indonesia.

Banyak penelitian menunjukkan bahwa kualitas guru adalah kunci utama dalam kinerja siswa. Bukti menunjukkan bahwa kualitas pendidikan guru memang berdampak pada hasil pendidikan guru dalam hal pengetahuan dan keterampilan guru (Blömeke et al. 2012), pada gilirannya, secara signifikan terkait dengan kualitas pengajaran dan prestasi siswa (Kersting et al. 2012). Di hampir semua negara, ada berbagai kegiatan pengembangan profesional, dari kelas yang sangat singkat hingga program komprehensif (Goldsmith et al. 2014). Ini termasuk program berbasis sekolah, dan pembinaan, seminar, atau jenis pelatihan di luar dan dalam-layanan lainnya dengan tujuan mendukung pengembangan kompetensi guru. Berdasarkan penelitian sebelumnya, dapat disimpulkan bahwa salah satu upaya yang bertujuan untuk meningkatkan pendidikan STEM adalah melakukan pendidikan guru STEM. Tiga untai pengetahuan teknisi yang dapat digunakan untuk mengembangkan pemahaman guru dan kemampuan guru dalam menguasai proses pembelajaran dijelaskan sebagai berikut: 
1. Pengetahuan Konten.

2. Pengetahuan Pedagogis.

3. Pengetahuan Konten Pedagogis. (Shulman, 1987)

Pengalaman pembelajaran dirancang untuk merangsang intensif mahasiswa dan pertanyaan tentang bagaimana calon guru dan guru mempersiapkan kegiatan menarik bagi siswa dan meningkatkan keterampilan mereka untuk menjawab keterampilan industri 4.0 dan abad ke-21 yang dibutuhkan. Untuk mengembangkan kegiatan, guru harus mempertimbangkan keterampilan proses sains tentang bagaimana ilmuwan berpikir dan bertindak.

Namun, guru harus fokus pada pengembangan kegiatan pembelajaran berdasarkan pendekatan STEM dengan berfokus pada beberapa ide besar dalam pembajaran sains. Kegiatan ini harus memberikan peluang dalam penyelidikan panjang yang berfokus pada satu masalah. Artinya, mereka tidak hanya berlatih dengan keterampilan proses sains mereka sendiri, tetapi juga memindahkan keterampilan ini karena mereka menggunakan pemikiran dan masalah kritis. Pada dasarnya, program ini fleksibel dan mudah beradaptasi. Menurut McKinsey (2016) Pengembangan Profesi Berkelanjutan memiliki potensi untuk memberikan insentif dan mendukung guru sepanjang kehidupan mengajar mereka dan untuk memanfaatkan hubungan yang ada dan potensial antara formal dan informal. Sementara itu, potensi Pendidikan STEM formal untuk meningkatkan pembelajaran siswa dan pendidikan guru STEM diakui, tetapi tetap kurang dieksploitasi.

Dalam beberapa tahun terakhir di Indonesia, minat STEM di sekolah meningkat pesat. Subjek tersebut bertujuan untuk menghilangkan penghalang antara keluaran sekolah dan pemangku kepentingan yang telah diinformasikan sebagai industri 4.0. Untuk memberikan kontribusi kepada masyarakat, sekolah harus memastikan hasil belajar anak memperoleh keterampilan dan aspirasi untuk berpartisipasi dalam masyarakat yang semakin ilmiah dan teknologi. Sebagai seorang pendidik (calon guru dan guru) harus menyadari apa yang merupakan keterampilan abad ke-21 dalam pendidikan. Untuk membuatnya lebih jelas, peta keterampilan telah diidentifikasi. Ini penting bagi semua peserta didik untuk berkembang ketika mereka maju melalui sistem pendidikan di setiap tahap McKinsey (2016).
Menurut Ejiwale (2012), ada lima karakteristik pelajaran STEM yang hebat. Yang pertama adalah pelajaran STEM fokus pada masalah dunia nyata dan fokus pada masalah. Dalam pelajaran STEM, siswa membahas masalah sosial, ekonomi, dan lingkungan yang nyata serta mencari solusinya. Karakteristik kedua adalah pelajaran STEM dipandu oleh proses desain teknik (EDP). EDP menyediakan proses yang fleksibel yang membawa siswa dari mengidentifikasi masalah atau tantangan desain untuk menciptakan dan mengembangkan solusi. Hal kedua yang harus dilakukan dalam proses ini, siswa menentukan masalah, siswa melakukan penelitian latar belakang, siswa menemukan dan mengembangkan banyak ide untuk solusi, mengembangkan dan membuat prototipe dan kemudian menguji, mengevaluasi produk yang mereka buat, pada akhirnya produk akan didesain ulang berdasarkan bagian evaluasi.

Karakteristik ketiga adalah pelajaran STEM membelajarkan siswa dalam penyelidikan dan eksplorasi terbuka. Dalam karakteristik ini, pekerjaan siswa adalah tangan dan kolaboratif, dan pembuat keputusan tentang solusi adalah respons siswa. Siswa mendapat akses berkomunikasi untuk membagikan ide-ide mereka dan mendesain ulang prototipe mereka sesuai kebutuhan. Karakteristik keempat adalah pelajaran STEM melibatkan siswa dalam kerja tim yang produktif. Karakteristik kelima adalah pelajaran STEM menerapkan matematika yang ketat dan konten sains yang dipelajari siswa. Lingkungan STEM menawarkan kemungkinan yang kaya dan lebih luas untuk solusi kreatif untuk menyelesaikan masalah.

Sanders (2009) menyarankan bahwa setiap pembelajaran STEM harus dirancang untuk memasukkan hasil belajar untuk setidaknya satu dari STEM lainnya, misalnya hasil pembelajaran matematika atau sains dalam kelas teknologi atau teknik (Sanders, 2009). Namun, definisi ini tidak secara eksplisit memasukkan fokus pada desain teknik dan konteks dunia nyata yang ditekankan oleh peneliti lain. Mereka mendefinisikan pendidikan STEM terintegrasi sebagai pendekatan instruksional di mana siswa berpartisipasi dalam desain teknik atau penelitian dan mengalami pembelajaran yang bermakna melalui integrasi dan aplikasi matematika, teknologi atau sains (Moore \& Smith, 2014). 
b) Praktik Terbaik Pendidikan STEM untuk Guru IPA

Pengembangan pandangan positif tentang sifat sains dan pengajaran matematika dan sains pada calon guru diperlukan karena guru sekolah dasar seringkali merupakan perwakilan pertama dari komunitas sains yang akan dihubungi oleh anak-anak dan pandangan guru pasti akan mempengaruhi pandangan siswa (Otero dan Gray 2008).

Pembelajaran berbasis proyek (PjBL) adalah cara lain teknologi dapat digunakan untuk memfasilitasi pembelajaran STEM dengan cara yang sejalan dengan praktik dunia nyata. PjBL telah lama dikenal sebagai pendekatan pengajaran konstruktivis yang efektif yang secara aktif melibatkan siswa dalam proses berbasis penyelidikan di sekitar pertanyaan dan tugas otentik (Blumenfeld, Fishman, Krajcik, Marx, \& Soloway, 2000; Blumenfeld, Soloway, Marx, Krajcik, Guzdial, \& Palincsar, 1991; Savery, 2006).

Verma, Dickerson, dan McKinney (2011) mengemukakan, PjBL juga "menjembatani [kesenjangan] antara akademisi profesi dan praktik profesi itu". Sebagai contoh, Marine Tech adalah program studi untuk siswa sekolah menengah dan atas yang memberikan instruksi dan pengalaman belajar langsung di bidang teknik kelautan, ilmu fisika, dan teknologi informasi yang berfokus pada pembuatan kapal (Verma et al., 2011).

Pengajaran yang berpusat pada siswa, kadang-kadang juga disebut sebagai pembelajaran yang berpusat pada siswa memungkinkan siswa lebih fleksibel untuk mengeksplorasi kreativitas mereka (misalnya, Costa, 2013; Motschnig \& Holzinger, 2002; Weimer, 2013; Wright, 2011). Melalui bentuk pengajaran yang berpusat pada siswa, minat siswa mendorong materi dan kegiatan; siswa mandiri, memiliki tanggung jawab dan akuntabilitas yang meningkat untuk pembelajaran mereka sendiri, dan terlibat dalam pembelajaran aktif (Gningue, et al, 2013). Dalam pengajaran yang berpusat pada siswa, guru bertindak sebagai fasilitator, lingkungan belajar kaya akan sumber daya dan aktivitas, dan siswa berkolaborasi dan berbagi satu sama lain (Russell et al., 2004).

Sejumlah peneliti telah mengidentifikasi praktik terbaik dalam pengembangan profesional guru, seperti pembelajaran aktif, peluang untuk merefleksikan praktik pengajaran, fokus pada pengetahuan konten, kedekatan dengan praktik di ruang kelas, dan waktu yang cukup untuk belajar dan menerapkan apa yang telah dipelajari. Studi dalam berbagai disiplin ilmu telah menunjukkan bahwa siswa yang terlibat dalam kurikulum terintegrasi berkinerja baik atau bahkan lebih baik daripada rekan-rekan mereka dalam pengajaran tradisional dengan disiplin ilmu yang terpisah (Czerniak, Weber, Sandmann, \& Ahern, 1999; Hinde, 2005). Selain itu, penggunaan kurikulum terintegrasi telah ditemukan untuk meningkatkan hasil belajar non-kognitif siswa, seperti minat dan motivasi (Erlandson \& McVittie, 2001). Penelitian empiris telah menunjukkan bahwa pendidikan STEM terintegrasi memiliki dampak positif pada prestasi siswa (Austin, Hirstein, \& Wallen, 1997). Selain itu, pendidikan STEM terintegrasi telah dilaporkan untuk meningkatkan keterampilan berpikir tingkat tinggi siswa dan literasi teknologi, menjadikan mereka pemecah masalah, inovator dan penemu yang lebih baik (Moore, 2012).

Dalam beberapa penelitian ditemukan bahwa sebelum melanjutkan dengan unit yang melibatkan siklus desain teknik, siswa diberi sesi persiapan bervariasi dari satu pelajaran tunggal untuk pertemuan mingguan. Sesi ini mencakup pengantar siklus desain teknik melalui diskusi dan bagaimana menangani atau menggunakan bahan-bahan LEGO (Wendell \& Rogers, 2013) yang nantinya akan digunakan sebagai bahan konstruksi di sepanjang unit. Selain itu, dalam sesi ini guru menekankan titik kunci dari desain teknik bahwa itu semua tentang brainstorming, perencanaan dan iterasi selama proses rekayasa berlangsung (Wendell \& Rogers, 2013; Yanyan et al., 2016). Studi lain (Yanyan et al., 2016) menerapkan pelatihan desain teknik selama dua jam per minggu selama lima minggu dan juga memberikan pelajaran pemanasan dalam bentuk tugas desain sebelum pembelajaran unit sains dengan desain teknik dimulai.

Universitas Pendidikan Indonesia sedang mengembangkan STEM Education mulai dari tahun 2014. Sejalan dengan penelitian tentang pendidikan STEM, Sejati (2017) dalam upayanya untuk meningkatkan kompetensi STEM siswa pada sistem tuas. Menurut Suwarna (2015) melakukan penelitian tentang metode yang diadopsi dari AS dan Jepang dalam mengembangkan aktivitas berbasis STEM. Hasil penelitian menunjukkan bahwa ada dua metode implementasi dalam pengaturan 
formal dan non-formal yang tertanam praktik rekayasa dalam kegiatan program memiliki hasil positif. Suwarna (2015) menjelaskan prosedur bagaimana membuat kolaborasi antara sekolah dan universitas, implementasi ini tertanam oleh praktisi di sekolah dan ahli STEM di universitas.

Selain itu, selama 2016 universitas ini juga melakukan beberapa penelitian tentang STEM. Selama tahun ini, peneliti menemukan inovasi dalam pengajaran sains telah berkembang. Menurut Permanasari (2016) pendidikan STEM adalah solusi alternatif untuk meningkatkan keterampilan siswa abad ke-21. Kegiatan pembelajaran dapat dilakukan dengan pembelajaran berbasis proyek, pembelajaran berbasis masalah, dan metode lain. Jauhariyyah (2016) meneliti STEM-PjBL dalam pembelajaran sains dan hasilnya menunjukkan bahwa STEM dapat meningkatkan literasi ilmiah, motivasi dan kreativitas. Khaeruningtias (2016) mengembangkan materi pembelajaran menggunakan pembelajaran 6L oleh Design TM pada suhu dan materi perubahannya dapat meningkatkan literasi ilmiah.

Pendidikan STEM memiliki hubungan positif untuk meningkatkan siswa berpikir tentang keberadaan wilayah Indonesia yang rawan gempa bumi dan masalah sumber daya manusia dan proses perencanaan tanggapan (Fitriani, 2016). Dia mengembangkan materi STEM tentang mempelajari proyek model bangunan tahan gempa. Nurlaley (2016) menggunakan masalah kasuistik selama implementasi pembelajaran berbasis STEM dengan PjBL tentang bioteknologi. Hasil menemukan model dalam pembelajaran sains sangat dianjurkan untuk meningkatkan prestasi literasi siswa STEM. Penelitian lain tentang proyek adalah membuat model perahu menuju literasi STEM siswa (Tati, 2017). Tati (2017) juga menunjukkan kepada kita bagaimana keterkaitan antara desain teknik terintegrasi dengan komponen STEM lainnya. Berdasarkan penelitiannya, pemahaman pengetahuan siswa terkait dengan tugas proyek mempengaruhi kegiatan desain teknik.

Prima (2018) menunjukkan dengan penelitian berkualitas tinggi dengan menggunakan Arduino-phet untuk memperbesar makna pendidikan STEM. Berdasarkan hasil penelitian menunjukkan bahwa peningkatan tinggi dapat dilihat setiap pertemuan, faktor-faktor ini dapat mempengaruhi literasi teknologi siswa dan hasilnya lebih tinggi dari yang lain. Implementasi dalam kegiatan STEM di kelas ditunjukkan di bawah ini:

\section{Identifikasi Masalah}

Sama seperti praktik penyelidikan, sains berbasis desain teknik juga dimulai dengan masalah yang dihadapi. Pada langkah ini siswa perlu membongkar tugas desain atau tantangan desain untuk memecahkan masalah dengan menggunakan pengetahuan ilmiah yang relevan. Untuk membantu siswa dalam mengidentifikasi tantangan desain, guru dapat menciptakan situasi dengan mengajukan masalah terstruktur yang diyakini sebagai perancah yang baik untuk belajar sains (Yanyan et al., 2016). Salah satu strategi perancah yang dapat digunakan adalah melalui penyajian masalah dalam bentuk data masalah tertentu (Barrett et al., 2014), atau melalui video, audio atau gambar yang disematkan (Schnittka et al., 2016).

\section{Mengemukakan solusi terbaik}

Setelah tantangan desain menyeluruh terungkap, siswa kemudian perlu mengumpulkan pengetahuan dan keterampilan yang diperlukan untuk mengembangkan solusi yang memungkinkan. Untuk melakukan ini mereka bekerja secara kolaboratif setidaknya dengan siswa lain sebagai angka dua atau sebagai tim dengan lebih dari dua siswa. Langkah ini bertujuan untuk membangun pengetahuan latar belakang dan keterampilan yang diperlukan untuk menyelesaikan tantangan desain. Ini dapat dilakukan melalui kegiatan langsung (Guzey et al., 2016) atau investigasi terbimbing (Wendell \& Rogers, 2013).

Cara efektif lain untuk mengeksplorasi solusi yang mungkin adalah melalui menggambar pada kartu desain (Yanyan et al., 2016). Menggambar dianggap sebagai kegiatan penting dalam desain teknik karena memungkinkan siswa untuk menganalisis kemajuan ide-ide lembur dan juga sebagai representasi dari konsep sains terkait (King \& English, 2016). Selain itu, King and English (2016) berpendapat bahwa sketsa yang dibuat oleh siswa akan membantu siswa untuk melihat teknologi, matematika, dan sains secara keseluruhan.

\section{Putuskan Solusi Terbaik}

Untuk meniru situasi dunia nyata, guru juga perlu memberikan tantangan desain dengan kendala ekonomi, estetika dan sosial untuk dipertimbangkan ketika siswa membuat 
keputusan dari solusi terbaik (Guzey et al., 2016). Contoh lain adalah ketika para siswa diminta untuk membangun rumah yang tahan terhadap tornado, guru hanya menyediakan persediaan terbatas namun struktur yang diperlukan masih terlihat seperti rumah, dengan dinding, atap, pintu, dan jendela (Barrett et al. , 2014).

\section{Bangun Prototipe}

Dalam langkah ini siswa perlu membangun artefak yang berfungsi berdasarkan desain solusi terbaik yang telah mereka pilih, yang memenuhi persyaratan tantangan desain menyeluruh (Wendell \& Rogers, 2013; Yanyan et al., 2016). Bangunan atau konstruksi mengacu pada pemodelan, menghasilkan alternatif, dan menggunakan kreativitas (Marulcu \& Barnett, 2016). Proses konstruksi dapat dikatakan sebagai bagian penting dari praktik desain teknik. Itu karena hasil konstruksi berfungsi sebagai mediator penting untuk pembelajaran siswa (King \& English, 2016; Wendell \& Rogers, 2013). Konstruksi memungkinkan siswa untuk terlibat dalam penalaran berbasis model, melakukan penyelidikan lebih dalam konsep sains dan mengeksplorasi hubungan matematika (Penner et al. Dalam Wendell \& Rogers, 2013). Sejalan dengan itu, Roth dalam (Wendell \& Rogers, 2013) memandang konstruksi sebagai representasi dari proses kognitif siswa dan dapat menjadi masalah yang akan dibahas di kelas. Selain itu, Kolodner et al. in (Wendell \& Rogers, 2013) berpendapat bahwa membangun produk yang berfungsi memberikan peluang bagi siswa untuk terlibat dalam penalaran ilmiah. Pada langkah ini, guru atau instruktur dapat memberikan bantuan dengan mengajukan pertanyaan terkait dengan konstruksi yang dibuat siswa (Barrett et al., 2014) untuk membantu siswa membongkar prinsip sains yang mendasarinya.

\section{Uji Prototipe}

Dalam menguji produk, siswa diberi beberapa kesempatan untuk memeriksa apakah fungsi konstruksinya baik atau tidak. Itu menyerupai eksperimen dan evaluasi praktik yang dilakukan oleh para insinyur nyata (Marulcu \& Barnett, 2016). Di tengah proses pengujian, guru dapat menindaklanjuti dengan menanyakan struktur mana yang masih lemah dan mengapa (Barrett et al., 2014). Dengan melakukan ini, siswa dapat menyelidiki prinsipprinsip sains yang mendasari lebih dalam melalui wacana ilmiah. Penggunaan pertanyaan cepat dalam jurnal teknik siswa juga bisa membantu (Wendell \& Rogers, 2013) untuk membimbing siswa dalam memeriksa apakah fungsi produk seperti yang diharapkan.

\section{Redesain dan Berkomunikasi}

Dari proses pengujian, siswa kemudian akan mengidentifikasi kelemahan tertentu dari produk mereka dalam menyelesaikan masalah, yang meliputi evaluasi, iterasi, dan optimisasi (Marulcu \& Barnett, 2016). Namun demikian, sebuah penelitian yang dilakukan oleh (King \& English, 2016) mengungkapkan temuan tak terduga bahwa proses mendesain ulang tidak memberikan peluang untuk elaborasi atau perluasan konsep sains dan matematika yang diterapkan dalam desain pertama. Dalam hal ini, siswa hanya fokus pada peningkatan penampilan fisik. Dalam pengaturan kamp STEM, kegagalan yang terjadi selama pengujian menghasilkan banyak percakapan sisi yang terkait dengan struktur konstruksi (Barrett et al., 2014). Ketika masih ada waktu yang cukup, siswa diizinkan untuk memodifikasi dan menguji ulang desain.

\section{KESIMPULAN}

Untuk menjawab abad ke-21 dan industri 4.0, STEM Education telah berkembang di seluruh dunia dan memiliki perubahan yang signifikan untuk meningkatkan pemahaman konsep, literasi, dan kreativitas siswa. Banyak penelitian memberikan bukti praktik terbaik bagi guru sains untuk menerapkan Pendidikan STEM. STEM memiliki hubungan dengan kehidupan sehari-hari yang dekat dan meningkatkan kesadaran siswa dengan lingkungan dan pendekatan ini dapat pula meningkatkan keterampilan siswa dalam membantu siswa berkualifikasi dan siap untuk kerja dibidang STEM. Mengenai Keterampilan Industri 4.0 dan Abad 21, pendekatan STEM mampu meningkatkan keterampilanketerampilan yang dibutuhkan siswa dalam menghadapi tantangan di era Industri 4.0 dan abad 21. Hal tersebut terlihat dalam bentuk kegiatan langsung dan berpusat pada siswa.

\section{DAFTAR PUSTAKA}

Austin, J. D., Hirstein, J., \& Walen, S. (1997). Integrated mathematics interfaced with science. School Science \& Mathematics, 97(1), 45-49.

Barrett, B. S., Moran, A. L., \& Woods, J. E. (2014). Meteorology meets engineering: an interdisciplinary STEM module for 
middle and early secondary school students. International Journal of STEM Education, 1(1), 6-11.

Blömeke, S., Suhl, U., Kaiser, G., \& Döhrmann, M. (2012). Family background, entry selectivity and opportunities to learn: What matters in primary teacher education? An international comparison of fifteen countries. Teaching and Teacher Education, 28, 44-55.

Blumenfeld, P. C., Soloway, E., Marx, R. W., Krajcik, J. S., Guzdial, M., \& Palincsar, A. (1991). Motivating project-based learning: Sustaining the doing, supporting the learning. Educational Psychologist, 26(3/4), 369-398.

Blumenfeld, P., Fishman, B., Krajcik, J., Marx, R., \& Soloway, E. (2000). Creating useable innovations in systemic reform: Scaling-up technology-embedded projectbased science in urban schools. Educational Psychologist, 35(3), 149164.

Burke,L.,Francis,K.,\& Shanahan, M. (2014).A horizon of possibilities : a definition of STEM education. McIntyre: Vancouver.

Bybee, R. B. (2013). The case for STEM education: Chalenges and Opportunities. Arlington : National Science Teachers Association, NSTA Press.

Czerniak, C. M., Weber, W. B., Sandmann, A., \& Ahern, J. (1999). A literature review of science and mathematics integration. School Science \& Mathematics, 99(8), 421-430.

Costa, M. J. (2013). What does 'studentcentered' mean and how can it be implemented? A systematic perspective. Biochemistry and Molecular Biology Education, 41(4), 267-268.

Ejiwale, J. A. (2012). Facilitating teaching and learning across STEM fields. Journal of STEM Education, 13(3), 87-94

Erlandson, C., \& McVittie, J. (2001). Student voices on integrative curriculum. Middle School Journal, 33(2), 28-36.

Farwati, R., Permanasari, A., Firman, H., \& Suhery, T. (2017) Integrasi Problem based learning dalam STEM education berorientasi pada aktualisasi literasi lingkungan dan kreativitas. Prosiding seminar nasional pendidikan IPA. Palembang
Farwati, R., Suhery, T., \& Permanasary, A., \& Firman, H. (2018) Integration of Science, Technology, Engineering and Mathematics: The Multidisciplinary Approach to Enhance the Environmental Literacy of Prospective Chemistry Teachers. Bulgarian Journal of Science EducationFitriani, D., Kaniawati, I., \&

Fitriani, D. N., Kaniawati, I., \& Ramalis, T. R. (2017). Creativity of junior high school's students in designing earthquake resistant buildings. IOP Conf. Series: Journal of Physics: Conf. Series 895

Gningue, S. M., Peach, R., \& Schroder, B. (2013). Developing effective mathematics teaching: Assessing content and pedagogical knowledge, studentcentered teaching, and student engagement. Mathematics Enthusiast, 10(3), 621-646.

Goldsmith, L., Doerr, H., \& Lewis, C. (2014). Mathematics teachers' learning: A conceptual framework and synthesis of research. Journal of Mathematics Teacher Education, 17, 5-36.

Guzey, S. S., Moore, T. J., Harwell, M., \& Moreno, M. (2016). STEM Integration in Middle School Life Science: Student Learning and Attitudes. Journal of Science Education and Technology, 25(4), 550-560.

Hinde, E. T. (2005). Revisiting curriculum integration: A fresh look at an old idea. The Social Studies, 96(3), 105-111.

Honey,M., Pearson,G.,\& Schweingruber,A. (2014). STEM integrationinK- 12 education: status, prospects, and an agenda for research. Washington: National Academies Press

Jauhariyyah, F. R., Suwono, H., \& Ibrohim (2017) Science, Technology, Engineering, and Mathematics Project Based Learning (STEM-PjBL) pada Pembelajaran sains. Pros. Seminar pend. IPA pascasarjana UM

Kelley, T. R., \& Knowles, J. G. (2016). A conceptual framework for integrated STEM education. International Journal of STEM Education, 3(1), 1-11.

Kersting, N. B., Givvin, K. B., Thompson, B. J., Santagata, R., \& Stigler, J. W. (2012). Measuring usable knowledge: Teachers' analyses of mathematics classroom videos predict teaching quality and 
student learning. American Educational Research Journal, 49, 568-589.

King, D., \& English, L. D. (2016). Engineering design in the primary school: applying stem concepts to build an optical instrument. International Journal of Science Education, 38(18), 2762-2794.

Marulcu, I., \& Barnett, M. (2016). Impact of an engineering design-based curriculum compared to an inquiry-based curriculum on fifth graders' content learning of simple machines. Research in Science \& Technological Education, 34(1), 85-104.

McKinsey, (2016). STEM Education in the Irish System School. A report of STEM Education. Irish

Moore, T. J., \& Smith, K. A. (2014). Advancing the state of the art of STEM integration. Journal of STEM Education : Innovations and Research, 15(1), 5-10.

Motschnig-Pitrik, R., \& Holzinger, A. (2002). Student-centered teaching meets new media: Concept and case study. Educational Technology \& Society, 5(4), 160-172.

Nurlaely, N., Permanasari, A., \& Riandi, R. (2017). Student's STEM literacy in biotechnology learning at junior high school. IOP Conf. Series: Journal of Physics: Conf. Series 895

Otero, V. K., \& Gray, K. E. (2008). Attitudinal gains across multiple universities using the physics and everyday thinking curriculum. Phys Rev Spec Top-PH, 4(2), 020104. https://doi.org/10.1103/ PhysRevSTPER.4.020104 .

Permanasari, A., \& Fitriani, A. (2016). Penerapan project based learning terintegrasi STEM untuk meningkatkan literasi sains siswa ditinjau dari gender. Jurnal Inovasi Pendidikan IPA, 2(2), 202212.

doi:http://dx.doi.org/10.21831/jipi.v2i2.8 561

Prima, E., C. et al (2018) STEM learning on electricity using Arduino-phet based experiment to improve $8^{\text {th }}$ grade students' STEM literacy. journal physics: conference series 1013012030

Russell, M., O'Dwyer, L., Bebell, D., \& Miranda, H. (2004). Technical report for the USEIT study. Boston, MA: Boston College, Technology and Assessment Study Collaborative.
Sanders, M. (2009). STEM, STEM education, STEM mania. The Technology Teacher, 68(4), 20-26.

Sejati, B. K., Firman, H., \& Kaniawati, I. (2017). STEM-Based workbook: enhancing students' STEM competencies on lever system. AIP conference proceedings 2848, 060005 (2017): doi: $10.1063 / 1.4983973$

Savery, J. R. (2006). Overview of problembased learning: Definitions and distinctions. Interdisciplinary Journal of Problem- Based Learning, 1(1), 9-20.

Schnittka, C. G., Evans, M. A., Won, S. G. L., \& Drape, T. A. (2016). After- School Spaces: Looking for Learning in All the Right Places. Research in Science Education, 46(3), 389-412.

Shulman, L. S. (1987). Knowledge and Teaching: Foundations of the New Reform. Harvard Educational Review, 57, 1-22.

Suwarma, I. R., Firman, H., \& Rustaman, N. Y. (2015) The development of technology and engineering literacy through STEMbased education. International Conference on Innovation of Engineering and Vocational Education. Atlantis Press

Suwarma, I. R., (2016) Pengaruh pembeljaran berbasis STEM pada konsep tekanan hidrostatis terhadap causal reasoning siswa SMP. Prosiding seminar nasional fisika

Tati, T., Firman, H., \& Riandi, R. (2017). The effect of STEM learning through the project of designing boat model toward student STEM literacy. IOP COnf. Series: Journal of Physics Conf. Series 895

Tsupros, N., Kohler, R., \& Hal linen, J. (2009). STEM education: A project to identify the missing components. Intermediate Unit 1and Carnegie Melon, Pennsylvania.

Verma, A. K., Dickerson, D., \& McKinney, S. (2011). Engaging students in STEM careers with project-based learning: Marine Tech project. Technology and Engineering Teacher, 71(1), 25-31.

Vilorio, D. (2014). STEM 101:Intro to tomorow's jobs. Occupational Outlook Quarterly. Retrieved from http:/www.stemedcoalition.org/wp content/uploads/2010/05/BLS- STEMJobs-report-spring-2014.pdf 
Weimer, M. (2013). Learner-centered teaching: Five key changes to practice (2nd ed.). San Francisco, CA: Jossey-Bass.

Wright, G. B. (2011). Student-centered learning in higher education. International Journal of Teaching and Learning in Higher Education, 23(3), 92-97.

Wright, V. H., \& Wilson, E. K. (2011). Teacher's use of technology: Lessons learned from the teacher education program in the classroom. Southeastern Regional Association of Teacher Educators (SRATE) Journal, 20(2), 4860.
Wendell, B. K., \& Rogers, C. (2013). Engineering Design-Based Science, Science Content Performance, and Science Attitudes in Elementary School. Journal of Engineering Education, 102(4), 513-540.

Yanyan, L., Zhinan, H., Menglu, J., \& TingWen, C. (2016). The Effect on Pupil's Science Performance and ProblemSolving Ability through Lego: An Engineering Design-based Modeling Approach. Journal of Educational Technology \& Society, 19(3) 156. 